\title{
MEMPROBLEMATISASI PERAN KOTA DALAM TATA KELOLA LINGKUNGAN GLOBAL
}

\author{
Gema Ramadhan Bastari \& Lathiefah Widuri Retyaningtyas \\ Aliansi Pemuda Pekerja Indonesia dan Perempuan Mahardika \\ Email : gemarbastari@gmail.com \& thyaz_1909@yahoo.co.id
}

\begin{abstract}
This paper will discuss about problems surrounding discourse on the role of local government or 'city' in global environmental governance. Many scholars, such as Acuto (2013), Betsill \& Bulkeley (2010) and Fraser (2014) have argued that city might be the missing actor that global environmental governance needs to make it work. However, this paper believes that the argument is riddled with fallacy, most notably with the way they did not take into account the existence of growth-based development ideology that can prevent local government from truly preserving the environment. This paper argues that city is not the panacea that will solve all environmental problems since it favors utilitarianism approach over deep ecology. However, this paper acknowledges that city could be the new norm entrepreneur that can strengthen international norm on environmental preservation.
\end{abstract}

Keyword: City, Environment, Norm, Utilitarianism

\section{PENDAHULUAN}

Dalam situasi sistem dunia yang semakin mengglobal saat ini, isu mengenai lingkungan hidup juga semakin bersifat transnasional. Keberlanjutan dan kelestarian lingkungan menjadi pembahasan yang sangat kompleks dalam ranah hidup manusia karena dampak - dampak dari permasalahan lingkungan ini dapat dengan jelas ditemukan tidak hanya pada satu kawasan tertentu tapi saling berkaitan antara satu dengan lainnya (mis. perubahan iklim, degradasi lingkungan, hujan asam, banjir, krisis energi, dsb.) (Betsill \& Bulkeley, 2010).

Pada perkembangannya, masalah-masalah seperti perubahan iklim akibat naiknya kadar emisi gas rumah kaca, penggundulan hutan, pencemaran limbah dan kerusakan lingkungan lainnya yang semakin hari semakin meningkat ini telah menimbulkan sebuah kesadaran baru akan pentingnya menjaga dan melestarikan lingkungan hidup. Kesadaran ini bahkan telah menjadi wacana yang digulirkan dan dibangun dari tingkat lokal, nasional bahkan internasional serta melibatkan banyak aktor yang berinteraksi di dalamnya. Aktoraktor yang terlibat dalam upaya untuk menyelesaikan permasalahan inipun sangat luas, mulai dari aktor negara, non-negara, masyarakat sipil, masyarakat adat, organisasi internasional, korporasi, pemerintah daerah, komunitas epistemik hingga pembentukan rezim-rezim inernasional untuk tata kelola lingkungan hidup global (Betsill \& Bulkeley, 2010). 
Betsill dan Burkeley (2006) berpendapat bahwa masalah lingkungan merupakan permasalahan yang bersifat global sehingga jawaban atas masalah ini harus diperoleh melalui proses negosiasi internasional antara negara-bangsa. Namun semakin jelas bahwa negara-bangsa tidak akan dapat memenuhi komitmen internasional mereka untuk mengatasi perubahan iklim tanpa keterlibatan aktor-aktor non-negara. Contoh kegagalan upaya negara-negara dalam mengatasi permasalahan lingkungan salah satunya dapat tercermin dari permasalahan seputar pengimplementasian Protokol Kyoto yang mewajibkan negara-negara industri untuk menekan tingkat emisinya, justru pada kenyataannya hingga saat ini negara-negara besar seperti Amerika Serikat dan Kanada, yang menjadi penghasil emisi karbon terbesar, tidak meratifikasi protokol tersebut. Hal ini menunjukkan bahwa tata kelola global ${ }^{1}$ melalui Protokol Kyoto tidak mampu mengendalikan perilaku negara-negara. Oleh karena itulah inisiatif-inisiatif lokal mulai dimunculkan sebagai perkembangan upaya dalam mengatasi permasalahan lingkungan global (Betsill \& Bulkeley, 2010). Salah satu inisiatif lokal untuk mengatasi isu lingkungan hidup yang berkembang dalam beberapa tahun terakhir adalah munculnya wacana bahwa pemerintah daerah atau kota dapat menjadi aktor sekaligus solusi bagi permasalahan lingkungan hidup.

Dalam hal ini, kota memiliki otoritas atas perencanaan penggunaan lahan dan pengelolaan limbah sehingga mereka dapat memainkan peran penting dalam menangani masalah transportasi dan konsumsi energi. Selain itu, kota bukan hanya memiliki kapasitas untuk memenuhi tujuan kebijakan yang telah ditetapkan dalam aturan nasional dan internasional, tetapi juga mampu mengambil inisiatif mereka sendiri; ini menunjukkan bahwa mereka merupakan aktor penting dalam tata kelola lingkungan global. Dalam gagasannya, Betsill dan Bulkeley (2010) menyatakan bahwa program Cities for Climate Protection (CCP) sebagai sebagai jaringan kota transnasional, dapat dikonseptualisasikan sebagai bagian dari tata kelola lingkungan global. Dimana CCP, dalam perspektif tata

\footnotetext{
${ }^{1}$ Tata kelola global (global governance) merupakan pola pemerintahan baru yang diamati oleh penelitipeneliti ilmu Hubungan Internasional pada akhir 90an. Ruggie (2014) mendefinisikan tata kelola global sebagai sistem otoritas norma yang dihasilkan melalui sinergi berbagai aktor di seluruh tingkatan sosial, mulai dari lokal, nasional, hingga internasional. Pola tata kelola global dapat terlihat di sejumlah fenomena dimana tidak ada otoritas tunggal yang sanggup untuk melakukan manajemen sendirian. Hal ini sangat relevan dalam isu perlindungan lingkungan hidup dimana tidak ada satu pun negara yang dapat menentukan kebijakan yang tepat untuk mengatasinya.
} 
kelola global, dapat berperan sebagai sebuah jaringan yang memediasi antara arena politik lokal, nasional hingga level global. CCP memberikan otoritas lokal kesempatan untuk mengambil posisi yang mungkin bertentangan dengan pemerintah nasional, hal ini menggambarkan bahwa tata kelola perubahan iklim tidak bisa dilihat secara hirarkis. CCP telah menciptakan arena tata kelolanya sendiri melalui pengembangan norma dan aturan untuk memenuhi tujuan dan target jaringannya. (Betsill dan Bulkeley, 2010).

Akan tetapi, wacana mengenai pentingnya peran pemerintah dalam tata kelola global juga perlu dikritisi kembali. Permasalahan utama yang akan diangkat oleh tulisan ini adalah kota, sebagaimana negara, juga didominasi oleh ideologi pembangunan yang berbasis pada pertumbuhan ekonomi. Menyikapi hal tersebut, tulisan ini mengajukan pertanyaan, "Bagaimana kota dapat menjadi solusi bagi permasalahan lingkungan hidup sementara mereka lebih mementingkan pertumbuhan ekonomi dibandingkan preservasi alam?" Pembahasan dalam tulisan ini akan dibagi menjadi tiga bagian. Bagian pertama akan menjelaskan urgensitas dari keberadaan aktor non-negara dalam tata kelola lingkungan global dengan menjelaskan faktor-faktor yang membuat negara tidak mampu mengatasi persoalan lingkungan hidup. Bagian kedua akan menjelaskan mengenai wacana kota sebagai jawaban atas permasalahan lingkungan hidup sementara bagian ketiga akan mengkritisinya. Pada bagian akhir, tulisan ini menyimpulkan bahwa kota tidak dapat menjadi panacea universal bagi persoalan lingkungan hidup, namun mereka tetap dapat menjadi aktor yang berperan signifikan dalam difusi norma internasional mengenai perlindungan lingkungan hidup.

\section{KERANGKA ANALISIS \\ PERMASALAHAN KEBIJAKAN LINGKUNGAN SECARA UMUM}

Permasalahan lingkungan bukanlah hal baru. Dampak dari kerusakan lingkungan sudah dirasakan semenjak Revolusi Industri di Inggris pada Abad ke-19. Akan tetapi, komunitas internasional baru menyepakati permasalahan lingkungan sebagai permasalahan global pada tahun 1992 ketika PBB mengadopsi United Nations Framework Convention on Climate Change (UNFCCC). Neil Carter (2001) melihat bahwa negara selalu lambat dalam mengatasi isu lingkungan. Negara cenderung menggunakan perspektif teknokrat memandang isu lingkungan sebagai sebuah permasalahan yang menghambat pembangunan ekonomi dan dapat diatasi melalui rekayasa ilmiah. Ketika Inggris dilanda polusi udara akibat industrinya, solusi yang ditawarkan pemerintah adalah membangun cerobong yang lebih tinggi. Mereka tidak menyadari bahwa asap dari cerobong yang tinggi tersebut 
akhirnya jatuh sebagai hujan asam ke negara-negara tetangganya di daerah Skandinavia. Kasus Inggris tersebut menunjukkan bahwa permasalahan lingkungan tidak dapat dilihat sebagai masalah yang dapat diatasi melalui pendekatan konvensional.

Menurut Carter (2001), terdapat lima alasan mengapa pendekatan konvensional dalam pembuatan kebijakan publik tidak dapat mengatasi permasalahan lingkungan. Pertama, lingkungan yang merupakan barang publik menyebabkan upaya negara dalam mengatasinya harus menghadapi perlawanan kolektif dari masyarakat. Lingkungan sebagai barang publik mengindikasikan bahwa keuntungan atau pun kerugian dari pemanfaatan lingkungan akan dirasakan oleh seluruh masyarakat. Sebagai contoh, jika negara ingin memberikan penambahan pajak bagi perusahaan yang berkontribusi bagi perusakan lingkungan, maka perusahaan akan berkoalisi dengan perusahaan lainnya untuk melobi pembuat kebijakan agar membatalkan kebijakan tersebut. Pada saat yang sama, jika pemerintah ingin menghimbau masyarakat untuk mengurangi aktivitas yang berkontribusi pada peningkatan polusi udara (mis. mengendarai mobil), maka masyarakat akan memiliki insentif untuk mengabaikan himbauan tersebut dengan asumsi bahwa orang lain akan melakukannya dan ia akan mendapatkan keuntungan yang sama. Pendekatan konvensional dalam pembuatan kebijakan yang cenderung one-dimensional tidak akan mampu mengatasi permasalahan lingkungan karena solusi bagi permasalahan lingkungan mensyaratkan kerjasama dari seluruh aspek masyarakat tanpa terkecuali.

Kedua, permasalahan lingkungan tidak mengenal batas negara. Sebagaimana dapat dilihat pada kasus Inggris sebelumnya, upaya mengatasi permasalahan lingkungan yang hanya dilakukan oleh satu negara berpotensi untuk mengekspor permasalahan tersebut ke negara lain tanpa benar-benar menuntaskan permasalahan itu sendiri. Dengan demikian, kebijakan untuk mengatasi permasalahan lingkungan harus dihasilkan dari kerjasama yang terkoordinir dari komunitas internasional. Ketiga, permasalahan lingkungan merupakan permasalahan kompleks yang melibatkan berbagai aspek dalam kehidupan. Dampak yang diakibatkan oleh kerusakan lingkungan mungkin berbeda-beda dan tersebar (mis. banjir, erosi, polusi), namun seluruh dampak tersebut saling terhubung dan mempengaruhi satu sama lain. Pendekatan konvensional dari negara yang hanya mengatasi dampak tersebut satu per satu tidak akan dapat menuntaskan permasalahan lingkungan secara utuh. Oleh sebab itu, dibutuhkan cara pandang yang lebih luas dan holistik untuk mengatasi permasalahan lingkungan (Carter, 2001). 
Keempat, permasalahan lingkungan membutuhkan penanganan ilmiah yang seringkali bertolak belakang dengan kepentingan politik. Kompleksitas dari permasalahan lingkungan membutuhkan penanganan serius dari orang-orang yang mendalami ilmu tentang lingkungan. Hal semacam ini umumnya mendapatkan perlawanan dari pihak-pihak yang diuntungkan oleh ketidaktahuan masyarakat terhadap kompleksitas dari permasalahan lingkungan. Jika masyarakat menyadari bahwa polusi disebabkan oleh pembuangan limbah dari perusahaan $\mathrm{X}$, maka perusahaan tersebut akan kesulitan dalam melanjutkan bisnisnya. Akibatnya, banyak penelitian mengenai permasalahan lingkungan yang dibajak oleh kepentingan pihak pendonor sehingga temuan yang dihasilkan menjadi jauh dari kebenaran. Kebijakan konvensional yang dibuat berdasarkan temuan semacam itu tidak akan dapat menuntaskan permasalahan lingkungan (Carter, 2001).

Kelima, struktur administrasi negara yang sangat terfragmentasi akan menghalangi mereka untuk menghasilkan kebijakan lingkungan yang holistik. Negara-negara neoliberal yang menempatkan pembangunan ekonomi sebagai prioritas utama umumnya memberikan otoritas penuh bagi kementerian-kementerian tertentu untuk memutuskan kebijakankebijakan yang mempengaruhi produksi, konsumsi, mobilitas, dan gaya hidup di negara tersebut. Kebijakan-kebijakan ini umumnya memiliki dampak negatif terhadap lingkungan (mis. pembangunan jalan mensyaratkan penebangan hutan), namun kementerian lingkungan yang mendapatkan otoritas untuk membuat kebijakan terkait lingkungan tidak memiliki hak untuk mengintervensi kebijakan kementerian transportasi. Prinsip birokratis yang dianut kebanyakan negara yang berupaya membagi permasalahan menjadi unit-unit kecil tidak akan berdaya menghadapi permasalahan lingkungan yang sangat kompleks. Kebijakan lingkungan yang efektif hanya akan dapat dihasilkan melalui kerjasama lintas sektoral, namun kompetisi antar-kementerian yang dihasilkan oleh struktur administrasi negara akan menghalangi terbentuknya kerjasama tersebut (Carter, 2001).

\section{METODE PENELITIAN}

\section{WACANA KOTA SEBAGAI JAWABAN BAGI PERMASALAHAN LINGKUNGAN}

Berbagai permasalahan dalam pendekatan konvensional yang dibahas di atas menunjukkan bahwa permasalahan lingkungan merupakan persoalan istimewa yang membutuhkan pendekatan baru. Sejumlah akademisi, seperti Acuto (2013), Betsill \& Bulkeley (2010), dan Fraser (2014) mengungkapkan bahwa kota merupakan solusi untuk memecahkan situasi ini. 
Dalam hubungan internasional, teori rezim dan konsep jaringan transnasional telah dikembangkan untuk menganalisis proses tata kelola lingkungan global. Namun Betsill \& Bulkeley (2010) menyatakan bahwa rezim biasanya diorganisir sebagai seperangkat perjanjian multilateral pada isu tertentu (misalnya, UNFCC dan Protokol Kyoto dalam kasus pemanasan global). Rezim dalam tradisi ini telah difokuskan pada kondisi yang efektif diciptakan dan dipelihara, dengan kata lain asumsi teori rezim yang lebih konsisten dengan perspektif pemerintah dan pendekatan rezim ini mengabaikan munculnya bentuk jaringan organisasi di mana memungkinkan hubungan kelembagaan terjadi secara langsung antara lokal dan internasional tanpa melalui pemerintahan. Hal ini menunjukkan kebutuhan untuk bergerak di luar konsep tradisional negara sebagai entitas nasional kekuasaan politik teritorial tertentu untuk memahami proses tata kelola lingkungan global.

Menurut Fraser (2014), dewasa ini kota telah menjadi tempat tinggal bagi sebagian besar penduduk sebuah negara. Tren mobilitas penduduk dalam beberapa dekade terakhir menunjukkan bahwa urbanisasi dari daerah perdesaan ke perkotaan semakin meningkat dengan tajam. Pembangunan ekonomi pun menjadi terkonsentrasi di daerah perkotaan. Sebagai akibatnya, berbagai isu yang berdampak pada permasalahan lingkungan, seperti transportasi dan penggunaan energi, ikut terkonsentrasi di kota. Dengan adanya kebijakan desentralisasi yang semakin memperkuat otoritas pemerintah lokal, Betsill \& Bulkeley (2010) berargumen bahwa pemerintah kota memiliki kekuasaan untuk menentukan kebijakan lingkungan, seperti pemanfaatan lahan dan manajemen limbah. Selain itu, kota juga memiliki kewenangan untuk melakukan kerjasama dengan kota di negara lainnya dan melampaui batas teritorial negara. Oleh sebab itu, mereka menyimpulkan bahwa kota dapat menjadi aktor utama dalam tata kelola lingkungan di tingkat global.

Dalam melihat problematisasi dari kota-kota global sebagai aktor kunci dalam tata kelola iklim, Acuto (2013) telah memberikan gambaran bagaimana C40 (Cities Climate Leadership Group) yang berasal dari konferensi kota-kota besar yang berdampingan membentuk program iklim telah semakin berkembang menjadi kolektif hibrida yang mampu berinteraksi dengan struktur kunci dari tata kelola global. Subpolitisasi dari tata kelola lingkungan telah dicapai oleh kota-kota global ini melalui jaringan transnasional yang mereka kembangkan dan pada saat yang sama sejajar dengan jalur politik internasional dan masyarakat sipil global (Acuto, 2013). 
Bagi C40, Perubahan iklim bukan semata-mata masalah lingkungan, namun terkait erat dengan tantangan pemberantasan kemiskinan dan meningkatkan inklusivitas. Kota memiliki kesempatan untuk meningkatkan standar hidup untuk semua manusia pada tingkat yang lebih cepat dengan mengikuti jalur pembangunan rendah karbon. Dengan argumen bahwa mengurangi ketidaksetaraan berarti membantu lingkungan, C40 berusaha untuk membangun bukti dasar dari manfaat tindakan terhadap iklim dan mengidentifikasi peluang untuk untuk membantu mengatasi ketidaksetaraan. Selain itu, C40 akan mengintegrasikan isu-isu tersebut ke dalam jaringan, komunikasi, adaptasi, keuangan dan program lain untuk memberikan sarana apa yang mereka butuhkan bagi walikota untuk mengatasi permasalahan lingkungan holistic (Acuto, 2013).

Gagasan menjadikan 'kota' sebagai jawaban atas permasalahan lingkungan juga dilihat oleh Acuto (2013) dalam pengaruh city leadership (kepemimpinan kota) pada tata kelola global. Acuto memberikan gambaran bahwa selama beberapa tahun terakhir telah terjadi peningkatan Kepemimpinan Kota pada Tata Kelola Global. Walikota sejauh ini telah mengulurkan tangan mereka untuk mengatasi pemanasan global atau migrasi. Walikota juga mampu menginspirasi pembuatan beberapa kerangka kerja kebijakan dan koalisi advokasi, mereka memperomotori tindakan-tindakan transnasional.

Walikota telah mempengaruhi tata kelola global melalui lima fitur non-eksklusif sebagai berikut: (1) Regime-building; Ada banyak bukti bahwa para pemimpin kota telah sangat proaktif untuk menghasilkan kerangka kerja kebijakan untuk bertindak, salah satu contoh terbaiknya adalah World Mayors Councilon Climate Change, dibangun pada December 2005 oleh Walikota Kyoto Yorikane Masumoto), (2) Hybridization of governance; hibridisasi dalam pengertian ini berfungsi pada beberapa faktor kebijakan. Pertama, mengikuti tren yang lebih luas dari dunia politik, jaringan kota yang semakin bergantung pada kemitraan publik-swasta untuk pelaksanaan dan pendanaan proyek. Kemudian, proses transnasional dipromosikan oleh walikota meliputi tidak hanya pemerintah daerah, tetapi juga organisasi internasional, lokal dan LSM transnasional, beberapa pemerintah pusat dan berbagai pelaku korporasi, seperti dalam kasus Cities Alliance atau the Canadian Sustainable Cities Initiative (Acuto, 2013).

Namun, hibriditas koneksi ini juga mencakup ke ranah ideologi politik: sifat publik-swasta dan multi-skalar, membuat jaringan kota cenderung menkonglomerasi berbagai pendekatan politik dunia atau yang disebut dengan (3) Diplomatic Entrepreneurship; walikota dapat terlibat dalam hubungan transnasional yang 
menempatkan mereka dalam hubungan dengan rekan-rekan perkotaan atau aktor politik lainnya, sehingga diplomasi kota dapat mengambil bagian dalam kancah internasional, (4) normative mediation; Walikota bahkan telah menunjukkan kapasitas untuk memainkan bagian penting dalam membina kerangka normatif internasional sebagai fungsi normatifnya, kota dapat secara aktif terlibat dengan standar hukum transnasional dengan mengadopsi kerangka kerja internasional yang belum diadopsi oleh pemerintah pusat mereka. Dalam hal ini kota menjadi mediator antara 'dunia' dan 'lokal', dan (5) Impact on 'everyday' international affairs; pemimpin kota merupakan jembatan mendasar antara narasi besar urusan internasional dan kekotaan sehari-hari mereka. Dengan internasionalisasi peran mereka di luar manajemen lokal, walikota terlibat dalam banyak jaringan kota, hal ini semakin menunjukkan bagaimana pemerintah pusat dan organisasi internasional bukanlah satu-satunya unit pemecah masalah dalam politik dunia (Acuto, 2013).

\section{PEMBAHASAN :}

\section{PROBLEMATISASI PERANAN KOTA DALAM TATA KELOLA LINGKUNGAN GLOBAL}

Tawaran-tawaran yang diajukan oleh Fraser (2014), Betsil \& Bullkeley (2010), dan Acuto (2013) telah membuka kemungkinan bagi penerapan metode alternatif dalam mengatasi permasalahan lingkungan yang menjawab persoalan-persoalan yang dihadapi metode konvensional. Akan tetapi, penulis melihat bahwa tawaran-tawaran tersebut masih sarat dengan perspektif utilitarianisme ${ }^{2}$ yang memandang lingkungan berharga sebatas instrumen untuk mendorong pembangunan ekonomi. Permasalahan lingkungan, dengan demikian, masih dianggap sebagai sebuah problema yang dapat dicari solusinya (problemsolving). Dalam hal ini, tata kelola lingkungan hidup global melalui peran kota menjadi

\footnotetext{
${ }^{2}$ Salah satu perdebatan abadi dalam etika lingkungan adalah perdebatan antara Ekologi Dalam (Deep Ecology) dan Ekologi Dangkal (Shallow Ecology). Konsep Ekologi Dalam pertama kali diperkenalkan oleh Arne Næss pada tahun 1973 sebagai sebuah perspektif yang memandang lingkungan dari segi spiritualitasnya. Dalam hal ini, Ekologi Dalam mempercayai bahwa manusia dan alam tidak dapat dipisahkan. Bahwa relasi manusia dan lingkungan didasarkan pada prinsip keseimbangan dunia yang menetapkan sebuah hukum bahwa salah satu tidak dapat hidup tanpa lainnya. Perpektif ini kemudian Næss kontraskan dengan ekologi dangkal yang ia anggap mengedepankan antroposentrisme dan utilitarianisme. Ekologi Dangkal mempercayai keterpisahan antara manusia dan alam. Bahwa alam ada semata-mata untuk dimanfaatkan oleh manusia sebagai bagian dari upaya mereka bertahan hidup. Næss berargumen bahwa perspektif ekologi dangkal inilah yang menjadi sumber bagi kehancuran lingkungan yang selama ini terjadi (Messersmith-Glavin 2011).
} 
solusi terbaru atas permasalahan lingkungan. Perspektif semacam ini menjadi problematik karena memprioritaskan keuntungan ekonomi sebesar-besarnya dan mengabaikan keberlanjutan dari lingkungan hidup. Sebagai contoh, Fraser (2014) dalam tawarannya untuk membangun agenda urban di ASEAN, lebih menitikberatkan pada peran kota sebagai pendorong pertumbuhan ekonomi dibandingkan peran kota sebagai aktor yang mampu melihat permasalahan lingkungan secara holistik (Varner, 2008).

Pemilihan kota sebagai aktor yang tepat untuk mengatasi permasalahan lingkungan juga dapat dikatakan oxymoron karena kota dan segala pembangunannya pun ikut berkontribusi terhadap perusakan lingkungan. Pembangunan kota mensyaratkan rekayasa total terhadap ekosistem dengan cara menyingkirkan unsur-unsur yang dianggap tidak bermanfaat bagi pertumbuhan kota. Tidak sedikit hutan rimba yang diratakan guna membangun gedung bertingkat, tidak sedikit pula daerah perairan yang disulap menjadi pusat perbelanjaan. Pembangunan kota dan penghancuran lingkungan adalah dua sisi koin yang tidak terpisahkan. Pertumbuhan kota juga akan menimbulkan berbagai konsekuensi yang akan semakin berkontribusi bagi perusakan lingkungan, di antaranya: urbanisasi dan kota sekunder (Schultz, 2014).

Kota yang semakin bertumbuh akan memusatkan segala kegiatan ekonomi di satu tempat. Hal ini kemudian menarik perhatian dari orang-orang yang tinggal di daerah pedesaan untuk mencari peluang dengan cara berpindah ke kota. Fenomena urbanisasi pun menyeruak ditandai dengan perpindahan massal dari masyarakat pedesaan ke kota. Akibatnya, populasi penduduk pun terpusat di kota dan menggandakan kebutuhan atas energi - kebutuhan yang lagi-lagi harus dipenuhi dengan merusak lingkungan (Roberts, 2014). Perpindahan manusia dari desa ke kota tidak hanya memindahkan beban desa ke kota, namun juga mentransformasi nilai-nilai yang dianut masyarakat pedesaan. Kehidupan di kota yang mensyaratkan persaingan ekonomi memperkuat nilai utilitarianisme dalam memandang lingkungan. Masyarakat pedesaan yang sebelumnya dapat puas hanya dengan mengapresiasi lingkungan di sekitarnya kini harus berjibaku untuk dapat bertahan hidup di kota. Dalam kondisi seperti itu, keberlangsugan lingkungan tidak akan lagi berarti bagi mereka. Situasi ini dapat terlihat pada pemukiman kumuh di daerah Sungai Ciliwung, Jakarta, dimana pelaku urbanisasi bertempat dan mengotori sungai di belakang rumahnya dengan sampah rumah tangga mereka (Zulwahyuni, 2007).

Kecenderungan pembangunan kota yang memunculkan keinginan dan pilihan individu untuk tinggal dan hidup di kota ini sangat berkaitan erat dengan tantangan yang 
mengarah pada semakin banyaknya kota sekunder akibat meningkatnya urbanisasi. Sebuah kota sekunder umumnya masuk dalam salah satu dari tiga jenis berikut: (1) Subnational Urban Center yang berfungsi untuk administrasi, manufaktur, agrikultur dan pengembangan sumber daya; (2) Metropolitan clustered secondary cities, yang berkembang di pinggiran daerah metropolitan atau kota, dan mengambil bentuk sebagai kota-kota baru, mencakup juga migran dan pengungsi kota; dan (3) Corridor secondary cities, yang berkembang sebagai kutub pertumbuhan utama koridor transportasi. Banyak kota-kota sekunder miskin harus dibenturkan dengan tekanan pembangunan yang dihasilkan dari urbanisasi. Kota besar ataupun sekunder sebenernya menghadapi permasalah yang sama mengenai persoalan lingkungan, hanya saja kota besar dinilai lebih mampu dalam hal pembiayaan (Roberts, 2014).

Masalah kerusakan lingkungan hidup dalam konteks perkotaan atau kawasan urban juga berkaitan dengan masalah kesenjangan ekonomi dan sosial. Terdapat kesenjangan diantara penduduk kota dalam memperoleh akses lahan tempat tinggal, sumber daya yang diperlukan untuk kebutuhan hidup, serta infrastruktur dan layanan dasar yang berkaitan dengan kesehatan lingkungan hidup. Misalnya karena akses yang terbatas kepada pemukiman resmi, penduduk miskin terpaksa membangun tempat tinggal secara ilegal di wilayah yang kualitas lingkungannya buruk sehingga sulit juga untuk memperoleh layanan air bersih untuk minum atau fasilitas sanitasi yang resmi (Isnaeni, 2016).

Betsill \& Bulkeley (2010) dan Acuto (2013) berargumen bahwa pemerintah lokal atau figur pemimpin kota dapat berperan signifikan dalam mewujudkan tata kelola lingkungan global. Argumen mereka didasari pada asumsi bahwa pemerintah lokal memiliki otoritas untuk menentukan perencanaan pembangunan kota. Mereka membuktikan asumsi tersebut dengan memaparkan institusi internasional, seperti CCP dan C40. Sampai taraf tertentu, keberadaan institusi tersebut memang membuktikan adanya peningkatan kesadaran terhadap tata kelola lingkungan global di tingkat lokal. Akan tetapi, kesadaran tersebut belum tersebar merata ke seluruh kota di dunia. Dalam beberapa kasus, pemerintah lokal justru terlibat dalam perusakan lingkungan dengan cara menjual izin pengelolaan lingkungan (mis. hutan) kepada perusahaan swasta. Kasus-kasus semacam ini dapat banyak ditemui di Indonesia, seperti di Pekanbaru, Samarinda, Kerinci, dsb. Hal ini menunjukkan bahwa pemerintahan lokal, kendati memiliki potensi untuk berperan dalam tata kelola lingkungan global, juga berpotensi untuk menghancurkannya. Sebagaimana 
dijelaskan oleh Carter (2001), tata kelola lingkungan hidup global yang tidak efektif berpotensi melahirkan free rider yang tidak mematuhi institusi internasional, namun menikmati keuntungan yang sama dengan pihak-pihak yang mematuhi.

\section{KESIMPULAN}

Pada akhirnya, tidak dapat disimplifikasikan bahwa 'kota' adalah jawaban dari permasalahan lingkungan global karena permasalahan lingkungan global mencakup dimensi yang sangat luas, mulai dari degradasi lingkungan, pembangunan, hingga kemiskinan. Tidak semua permasalahan lingkungan bisa di selesaikan tingkat kota, namun upaya untuk membangun unsur-unsur kota baik itu gerakan sosial yang ada di kota maupun komunitas epistemik yang ada dikota serta aktor lain yang mampu terlibat dalam upaya pelestarian lingkungan secara menyeluruh memiliki potensi untuk dapat menjadi embrio-embrio enterprenir norma yang signifikan. Menurut Finnemore dan Sikkink (1998), enterprenir norma memiliki peranan penting dalam memperkenalkan dan mempromosikan sebuah norma yang dapat berevolusi menjadi norma internasional. Syaratnya adalah enterprenir norma harus memiliki koneksi ke institusi formal internasional untuk dapat mengangkat norma mereka ke dimensi transnasional. Dalam hal ini, C40 dan CCP dapat menjadi panggung yang relevan bagi kota-kota di seluruh dunia untuk melakukan difusi terhadap norma internasional mengenai perlindungan lingkungan hidup.

Kota-kota di Indonesia sesungguhnya memiliki potensi besar untuk menjadi enterprenir norma yang berpengaruh di tingkat transnasional. Kompetisi Adipura yang rutin diselenggarakan di Indonesia menunjukkan bahwa kota-kota sudah mampu untuk menunjukkan kepedulian terhadap lingkungan dengan insentif kompetisi. Tidak hanya itu, kota-kota sekunder seperti Bandung, Semarang dan Surabaya juga telah berhasil mempopulerkan isu lingkungan hidup dan menjadikannya sebagai bentuk kebanggaan dari warga terhadap kotanya. Jika semangat yang sama dapat diteruskan ke tingkat transnasional, maka hal ini akan mengakselerasi proses difusi untuk pembentukan norma internasional mengenai perlindungan lingkungan hidup. Kota Semarang bahkan telah melakukan ini dengan terpilih sebagai nominator untuk mewakili Indonesia di ajang ASEAN Clean Tourist City (Maharani 2017). Dengan demikian, penulis berargumen bahwa fokus yang diarahkan seharusnya bukan kepada kota sebagai pembuat kebijakan dan solusi 
bagi permasalahan lingkungan, melainkan kota sebagai ruang untuk melahirkan normanorma baru yang mendukung terciptanya tata kelola lingkungan global.

\section{DAFTAR PUSTAKA}

Acuto, Michele. 2013. City Leadership in Global Governance. International Studies Association Annual Convention,San Francisco.

Acuto, Michele. 2013. The New Climate Leader?. Review of International Relations. p.123

Isnaeni, Nurul. dkk. 2016. Tata Kelola Lingkungan Hidup Global. Depok. Serat Alam Media.

Betsill, Michele M \& Herriet Bulkeley. 2010. Cities and the Multilevel Governance of Global Climate Change, dalam Global Governance. Vol. 12 No.2

Brian H. Roberts, 2014, Managing Systems of Policy Responses in International Development Secondary Cities. Cities Alliance.

Carter, Neil. 2001. The Politics of the Environment: Ideas, Activism, Policy. Cambridge: Cambridge University Press.

C40 Cities Climate Leadership Group dalam http://www.c40inclusivecities.org

Finnemore, Martha, \& Sikkink, Kathryn. (1998). International Norm Dynamics and Political Change. International Organization Vol. 52 No. 4 , 887-917.

Fraser, Rowan. 2014. Why ASEAN needs An Urban Agenda?. Asia Development Dialogue. http://www.asiadialogue.org

Schultz, Colin. 2014. Urbanization Has Been Destroying the Environment Since the Very First Cities. Smithsonian Magazine.

Varner, Gary. 2008. Utilitarianism and the Evolution of Ecological Ethics. Sci Eng Ethics. Sringer Science+Business Media.

Zulwahyuni, Hamna. 2007. Analisis Relokasi Pemukiman Penduduk di Sempadan Sungai Ciliwung dengan Pendekatan Wilingness to Accept. Institut Pertanian Bogor.

Maharani, Esthi. Semarang Jadi Nominator Kota Bersih ASEAN. Oktober 4, 2017. http://nasional.republika.co.id/berita/nasional/daerah/17/10/04/oxa1gp335semarang-jadi-nominator-kota-bersih-asean (accessed Oktober 4, 2017).

Messersmith-Glavin, Paul. Between Social Ecology and Deep Ecology: Gary Snyder's Ecological Philosophy. 2011. https://theanarchistlibrary.org/library/paulmessersmith-glavin-between-social-ecology-and-deep-ecology-gary-snyder-secological-philos (accessed Oktober 4, 2017).

Ruggie, John Gerard. "Global Governance and "New Governance Theory": Lesons from Business and Human Rights." Global Governance Vol. 20, 2014: 5-17. 